\title{
B Pesearch S Surare \\ Cloning, expression, purification and amyloid degradation study of recombinant serrapeptase from Serratia marcescens
}

\section{R Venkataprasad}

SRM Institute of Science and Technology

Shreya Gopinath

SRMIST: SRM Institute of Science and Technology

Ethiraj Selvarajan ( $\square$ selrajan@gmail.com )

SRMIST: SRM Institute of Science and Technology https://orcid.org/0000-0002-3447-6432

\section{Research Article}

Keywords: Serrapeptase, Cloning, Expression, Insulin amyloid degradation

Posted Date: April 15th, 2021

DOI: https://doi.org/10.21203/rs.3.rs-346758/v1

License: (c) This work is licensed under a Creative Commons Attribution 4.0 International License.

Read Full License 


\section{Abstract \\ Background}

Serrapeptase (SP) is a proteolytic enzyme which plays a prominent role in the degradation of dead tissue. It can also use as a therapeutic enzyme for the treatment of Insulin amyloids. It has reported that the SP protein has the fibrinolytic activity, but the activities towards insulin amyloid degradation not reported. Our study has focused the cloning and expressing SP gene and studying its cytotoxic reactivity studies and amyloids degradation.

\section{Results}

SP gene was cloned in pET-28 a (+), and the enzyme was expressed using E.coli BL 21 (DE3) strain. The clone was confirmed using colony PCR, sequencing and restriction digestion. Overexpression of enzyme and purification performed using IPTG and Ni-NTA column. The molecular weight of serrapeptase protein was determined using SDS-PAGE, which found to be $52 \mathrm{kDa}$. The purified enzyme showed a zone of clearance on casein plate, slight cytotoxic reactivity to PC- 12 cells after $24 \mathrm{~h}$ contact and $25 \%$ insulin amyloid degradation confirmed after $24 \mathrm{~h}$ of incubation.

\section{Conclusion}

This study shows that cloning and the expression of SP will reduce the time and cost of production of SP from wild type strain which can be used for the treatment of amyloid-related diseases.

\section{Background}

Amyloidosis is amyloid-related diseases caused due to improper folding of proteins. It also leads to the accumulation of insoluble fibrillary aggregates. Depositions of amyloid fibrils are toxic and are associated with diseases like Alzheimer's disease, Parkinson's disease, Type II diabetes and CreutzfeldtJakob disease [1]. The shift of the protein from a soluble state to the insoluble state is still unknown [2]. Insulin is a protein that used as a therapeutic for the treatment of diabetes which forms insoluble insulin amyloids due to repeated localized insulin injections [3]. These insulin amyloids referred to Alns by The Nomenclature Committee of the International Society of Amyloidosis [4]. In 1983, the first case for insulin amyloids reported. Between 2012 and 2015, there are about 75 cases reported with insulin amyloids. In 1983 , the first case for insulin amyloids reported. Even after cessation of insulin injections, the insulin amyloid mass can continue to develop. The insulin amyloid formation is also associated with the latest model of insulin administration as inhalation of powdered insulin [5]. Insulin amyloids possess a common cross $\beta$-structure compared to native amyloids like prion, synuclein and $\beta$-amyloid. Thus insulin can be used as a model protein to study the inhibitors for amyloid-related diseases. Enzymes are biocatalysts for most of the chemical reaction and have been used prevalently for therapeutic purposes 
[6]. The sources for the enzymes are the microbes, plants and animals. Production of microbial enzymes is simple, time for production is less, and cell doubling time is less compared with plants and animalbased enzymes [7]. Protein is digested to peptide bonds by hydrolase belongs to proteolytic enzymes family [8], and plays a prominent role in degrading the protein mass accumulated in the body [9].Serrapeptase (EC number 3.4.24.40) is a proteolytic enzyme which was used in Asia and Europe for 25 years. In 1977, it was first introduced in the US. It is isolated initially from the enterobacteria Serratia marcescens strain E-15 found in the gut of the Japanese silkworm Bombyx mori. It is originated from $S$. marcescens which secretes the protease extracellularly and thus it is also termed as Serratiopeptidase or Serratia peptidase [10]. SP acts effectively towards the dead proteins at the end of silkworm threads and specifically, it degrades the proteins involved in non-living tissues found in the cocoon [11]. The SP doesn't act against the living cell; it will act only against the non-living cells [12]. SP has properties like anti-oedemic, analgesic, anti-inflammatory, degrades non-living tissues such as mucous, plaques and blood clots. SP used to treat atherosclerosis, arthritis, bronchitis, fibrocystic breast disease, Crohn's disease, traumatic swelling, fibromyalgia, breast engorgement, migraine, Alzheimer's disease, hepatitis, lung disorders, arthritis, diabetes, carotid artery blockage, thrombosis[13].SP activity towards chronic disorders is under process. Since it has insulin amyloid degradation activity it is used to treat amyloidosis associated diseases [14].The SP gene was sequenced and its crystal structure was determined [16]. The gene SPcontains 470 amino acids and sulphur free molecule [17]. SP has $58 \%$ of $G+C$ for the coding region of the protein [15]. SP has a molecular weight of about $45 \mathrm{kDa}-60 \mathrm{kDa}$. pPICZa A Pichia expression vector was used to clone SP gene and it is transformed into Pichia pastoris GS115.The highest expression of the gene was observed at $72 \mathrm{~h}$ and alternative expression systems are $E$. coli and Yeast can be used[22]. The gene from Serratia marcescens was cloned in pTSP26 and the recombinant plasmid was expressed in E. coli-JM 103 the enzymes are expressed inside the cell and in the medium [15]. A study showed that the SP gene expressed using E.coli lac promoter produced inactive protein in the medium with a higher molecular weight [18]. The SP gene expressed in E.coli (DE3)/pLysS strain by the expression vector pET32a (+), it resulted in inclusion body formation and it is found to be dormant [19]. SP gene was cloned by using pET28 vector and expressed in the expression system of E. coli BL21. This showed no formation of inclusion bodies in the cytoplasm, and mostly expressed in the culture medium as extracellular protein and a small amount was expressed in the cell [20]. The gene was cloned PJET 1.2 vector and it is expressed in the $E$. coli DH5- $\mathrm{a}$ and the obtained sequence showed that cloning in In-frame. The SP gene sequenced was found to be having 1464 base pairs [21]. Hence pET-28 and pJET series vectors are found to be the most suitable for the expression of SP in E. coli without resulting inclusion bodies.

In this study, we have cloned the SP gene in the pET-28 a (+) vector, and the clone confirmation was done by restriction digestion and colony PCR. Forward sequencing was done to confirm the directional of cloning and the enzyme was expressed using E.coli BL21 strain. Nickel affinity chromatography was used for the purification of the extracted enzyme. Furthermore, the purified enzyme was used to perform the caseinolytic assay and Insulin amyloid degradation assay. 


\section{Methods}

Serratia marcescens strain was purchased from MTCC, Chandigarh with the strain number MTCC 8708. Taq DNA polymerase master mix RED was purchased from Ampliqon, Phusion High-Fidelity DNA Polymerase mix, Restriction enzymes, T4 DNA ligase was purchased from New England Biolabs (NEB). Luria- Bertani (LB) media, LB broth, Ampicillin, Kanamycin, Streptomycin Ni-NTA resin with the column was purchased from Hi-Media. IPTG was purchased from SRL chemicals. Primers are ordered from Shrimpex Biotech service Pvt. Ltd. PCR clean up kit were purchased from Smart prime Itd. Huminsulin 30/70 $40 \mathrm{IU} / \mathrm{mL}$ cartridge was purchased from Eli Lilly Pvt Ltd.

\section{Inoculum preparation}

S. marcescens obtained from MTCC was cultured on nutrient agar and incubated at $37^{\circ} \mathrm{C}$ for $24 \mathrm{~h}$. A single colony from the plate was inoculated into the sterile nutrient broth and incubated at $37^{\circ} \mathrm{C}$ for 24 h. coliTOP10 was inoculated in LB broth containing Streptomycin $(50 \mu \mathrm{g} / \mathrm{mL})$ from the glycerol stock culture. E.coliBL21 was plated on LB agar and incubated at $37{ }^{\circ} \mathrm{C}$ for $24 \mathrm{~h}$. A single colony from the plate was inoculated into the sterile nutrient broth and incubated at $37^{\circ} \mathrm{C}$ for $24 \mathrm{~h}$. All the strains were maintained in LB broth for further research work.

\section{Isolation of plasmid from E.coli using alkaline lysis method}

pET-28 a (+) vector was isolated by inoculating the single colony in $100 \mathrm{~mL}$ of LB broth with kanamycin antibiotic and incubated at $37^{\circ} \mathrm{C}$ for $16 \mathrm{~h}$. Further, the cells were pelleted down by centrifuging at 12,000 $\mathrm{rpm}, 4^{\circ} \mathrm{C}$, for $5 \mathrm{mins}$. The supernatant were discarded and the pellets dissolved in $10 \mathrm{~mL}$ of alkaline lysis buffer I containing 50mM Glucose, $25 \mathrm{mM}$ Tris HCl, 10mM EDTA, pH 8.0 and vortexed vigorously. Then 8 $\mathrm{mL}$ of Alkaline lysis buffer II $(0.2 \mathrm{NaOH}, 1 \% \mathrm{SDS})$ was added and tubes were inverted several times with incubation in ice for $3 \mathrm{~min}$ to mixed down the solution. Finally, $6 \mathrm{~mL}$ Alkaline lysis buffer III was added to the solution and the tubes were inverted several times to mix it properly. Centrifuge at maximum speed for $20 \mathrm{~min}$ at $4^{\circ} \mathrm{C}$, residues discarded. The supernatant were transferred to a fresh micro-centrifuge tube. Then an equal volume of ice-cold isopropanol was added and incubated at $4{ }^{\circ} \mathrm{C}$ for $30 \mathrm{~min}$ and centrifuged at maximum speed for $15 \mathrm{~min}$. Then pellet was washed using $70 \%$ ethanol. Then the supernatant was discarded, air-dried until the ethanol smells go off. Pellet dissolved in TE buffer pH8.0 stored at $-20{ }^{\circ} \mathrm{C}$. Then the isolated plasmid visualized in $0.8 \%$ agarose gel. RNase A treatment given for $3 \mathrm{~h}$ and isopropanol precipitation steps were repeated, visualized in $0.8 \%$ agarose gel [26].

\section{Cloning of SP gene in pET- 28 a (+)}

The SP gene was amplified from isolated genomic DNA using the forward and reverse primer (Table 1) with Nde I and Hind III restriction site respectively. The primers are designed by Primer 3 software using the SP gene sequence [22]. These enzymes determined using the NEB Cutter online tool to identify which restriction sites were not present in the desired sequence. The restriction enzymes were high fidelity in nature. It has $100 \%$ compatibility in cutsmart buffer so double digestion could be easily performed 
instead of halting the reaction after one digest and continuing the next set of digestion after the first set of reactions has completed. $1 \mu \mathrm{g}$ of purified insert and vector are used for setting up a restriction digestion reaction. Single digestion with each enzyme was also set for the vector to check whether the two restriction enzymes were working. The digested vector and insert are gel eluted to obtain gene without the restriction components to prevent further acts of restriction enzymes on the DNA samples. Then the purified vector and insert are ligated using the T4 DNA ligase enzyme. The restriction and ligation reaction is performed according to the NEB Cloning protocol. The cloned gene was transformed to E.coli TOP10 competent cells and then colony PCR was performed to confirm the recombinant vector transformation. Then plasmids from the positive colonies are isolated and then transformed to the E.coli BL 21 for expression of SP gene. Cloning was confirmed by colony PCR, and restriction digestion was performed to check the release of insert form vector.

\section{Expression of SP enzyme}

The positive colony with the desired gene of interest confirmed by colony PCR and re-digestion was inoculated in LB broth with kanamycin $(50 \mu \mathrm{g} / \mathrm{mL})$ incubated in shaking incubator for overnight at $37^{\circ} \mathrm{C}$. From the overnight grown culture, $1 \%$ was transformed to new LB broth of $10 \mathrm{~mL}$ and incubated at $37^{\circ} \mathrm{C}$ till it reaches the OD at $600 \mathrm{~nm}$ in the range of 0.4-0.6. Then IPTG (HiMedia) of $1 \mathrm{mM}$ final concentration was added to the culture and incubate at $37^{\circ} \mathrm{C}$ for $4 \mathrm{~h}$ and $16 \mathrm{~h}$. GFP protein expression was used as a positive control.

The positive colony with the desired gene of interest was inoculated in LB broth incubated in shaking incubator for overnight at $37^{\circ} \mathrm{C}$. From the overnight grown culture, $1 \%$ was transformed to new LB broth of $10 \mathrm{~mL}$ and incubated at $37^{\circ} \mathrm{C}$ till it reaches the $0.4-0.6$ OD value at $600 \mathrm{~nm}$. Then IPTG of $1 \mathrm{mM}$ final concentration was added to the culture and incubate at $37^{\circ} \mathrm{C}$ for $4 \mathrm{~h}$ [22]. GFP protein expression was used as a positive control.

\section{Ni Affinity Chromatography}

After the sonication process, the crude extract of the recombinant protein was purified using Ni Affinity chromatography method. Therefore, only an $\mathrm{N}$-terminal $6 \mathrm{XHis}$-tag is on the recombinant protein which will bind to the $\mathrm{Ni}$ in the $\mathrm{Ni}$ affinity resin column. The Ni Affinity resin was passed through the column and allowed the resin to settle down in the column. Then crude extract was passed through the column and flow through was collected. Wash buffer with $20 \mathrm{mM}$ Imidazole was used to remove the loosely bounded protein. Finally, Elution buffer with $300 \mathrm{mM}$ of Imidazole was used to elute out the purified recombinant protein. Again the wash buffer was used to clean the column to remove thoroughly the residual proteins from the column. Then purified enzyme was subjected to different assays to check the activity ${ }^{[23]}$.

\section{SDS PAGE}

The crude extract, flow-through, purified enzyme, induced cell extract; wild type strain cell extract was loaded in the SDS PAGE to check the molecular weight of the protein and to show the difference in 
protein expression and concentration [24]. The separating gel was $12 \%$ and the stacking gel was $5 \%$ was used to perform the SDS PAGE. The SDS gel was strained for $4 \mathrm{~h}$ in a staining solution containing a pinch of Coomassie brilliant blue R-250, 10 \% glacial acetic acid and $50 \%$ Leishman stain, $40 \%$ distilled water. SDS gel was destained for overnight on gel rocker in $60 \%$ Leishman stain $30 \%$ glacial acetic acid and 10 $\%$ water.

\section{Protease assay}

The protease activity of SP was performed using casein as a substrate as mentioned in Sigma's Nonspecific protease activity assay. Briefly, $5 \mathrm{~mL}$ of casein solution was incubated at $37^{\circ} \mathrm{C}$ for $5 \mathrm{~min}$ and then $1 \mathrm{~mL}$ of the enzyme to be tested is added to it and incubated at $37^{\circ} \mathrm{C}$ for $10 \mathrm{~min}$. to stop the reaction, 5 $\mathrm{mL}$ of TCA is added and insoluble particles are filtered using syringe filter. Then $5 \mathrm{~mL}$ of sodium carbonate is added and $1 \mathrm{~mL}$ of Folin's reagent was added to the solution immediately and OD value was measured at $660 \mathrm{~nm}$. The protein content of the enzyme was determined by the Bradford method [25].

\section{In vitro insulin amyloid formation and degradation}

Insulin amyloids were formed by incubating Huminsulin $30 / 7040 \mathrm{IU} / \mathrm{mL}$ at $65^{\circ} \mathrm{C}$ for various time intervals from $2 \mathrm{~h}$ to $24 \mathrm{~h}$. At each interval, SP was added to the insulin amyloid formed and incubated the mixture at $37^{\circ} \mathrm{C}$ for $1 \mathrm{~h}$. The formation of insulin amyloid and degradation of insulin amyloid by SP was confirmed by turbidity assay and FTIR analysis [14].

\section{Turbidity assay}

Insoluble protein aggregates can be estimated at $600 \mathrm{~nm}$. Hence the insoluble insulin amyloid fibrils can be detected at $600 \mathrm{~nm}$ using UV VIS spectrophotometer. $10 \mu \mathrm{l}$ of formed insulin amyloids at each time interval and the SP treated samples at each time interval were diluted with $1 \mathrm{~mL}$ of PBS $(10 \mathrm{mM}, \mathrm{pH} 7.4)$ and the OD was measured at $600 \mathrm{~nm}$ using a UV spectrophotometer[14].

\section{Caseinolytic assay}

The transformed colonies of E.coli BL21 with the recombinant plasmid was expressed using the $1 \mathrm{mM}$ IPTG and then sonication was to isolate intracellular expressed enzyme and the recombinant enzyme was purified by Ni-NTA column. The purified sonicated sample and supernatant was loaded in the casein plate. The plate was incubated at $37^{\circ} \mathrm{C}$ for 16 hours and checked for the zone clearance at patched sites [24].

\section{In vitro cytotoxicity}

An in vitro cytotoxicity test method was performed for the given test sample as per ISO 10993:5. The culture medium from the PC-12 cells was replaced with fresh medium. Test sample in triplicates was added on the cells. After incubation at $37 \pm 1^{\circ} \mathrm{C}$ for $18 \mathrm{~h}, \mathrm{MTT}(\mathrm{mg} / \mathrm{mL})$ was added in all the wells and 
incubated for $4 \mathrm{~h}$. After incubation, DMSO was added in the wells and read at $570 \mathrm{~nm}$ using a photometer. Cytotoxicity and cell viability were calculated by the below formula. (Table 2)

Cytotoxicity $=[($ Control - Treated $) /$ Control $] * 100$

Cell viability $=($ Treated $/$ Control $) * 100$

\section{Results}

\section{Cloning of SP gene in pET-28 a (+)}

The primers condition for the PCR amplification of the SP gene was first optimized by using Taq DNA polymerase and then the same primer condition was followed to amplify the gene without any mutation using Phusion DNA polymerase. The PCR amplified product was purified using the PCR clean up Kit to remove the unused dNTPs, buffer, Taq polymerase, primers, it may extend the restriction digested product with sticky end to blunt end and so cloning cannot be done and then the sample was loaded in $0.8 \%$ agarose gel (Fig 1). The plasmid DNA isolated by the alkaline lysis method has more of RNA contamination and so it was removed by treating the sample with RNase $A$ for $2 \mathrm{~h}$. The RNA plasmid concentration was found to $180 \mathrm{ng} / \mu \mathrm{l}$. Isopropanol was added to isolate only the plasmid DNA from the RNA treated plasmid sample. Then plasmid was purified by PCR clean up kit and sample was loaded in agarose gel of $0.8 \%$. The purified plasmid and the PCR product was double digested using the restriction enzymes Hind III and Nde I for $3 \mathrm{~h}$ at $37^{\circ} \mathrm{C}$ in the static incubator. The digested product was subjected to heat inactivation process for $20 \mathrm{~min}$ at $80^{\circ} \mathrm{Cin}$ water bath and then purified by gel elution method to remove the restriction digestion component to prevent further digestion process during the ligation reaction and then it was used for setting up the ligation reaction. The ligated product transformed to E.coli TOP10 which has high transformation efficiency and the transformation was confirmed by Colony PCR (Fig 2), the positive colony was patched on LB agar plate with Kanamycin antibiotic (50 $\mu \mathrm{g} / \mathrm{mL}$ ) and also glycerol stock also prepared which is stored at $-80^{\circ} \mathrm{C}$. The plasmid form the positive clones are isolated and then it is transformed into the expression system E.coliBL21. The plasmid isolated from the positive colony was subjected to restriction digestion and the release of insert form vector was observed in the $1 \%$ agarose gel this confirms the directional cloning of SP gene in pET-28 a (+) (Fig 3).

\section{Expression, purification of SP and SDS PAGE}

Single colony of E.coli BL 21 with recombinant plasmid was grown in LB broth with kanamycin (50 $\mu \mathrm{g} / \mathrm{mL}$ ) for overnight and then reinoculated in fresh LB broth with same antibiotic along with IPTG (1mM) incubated for $4 \mathrm{~h}$ and $16 \mathrm{~h}$. The recombinant SP gene alone continuously expressed by binding of IPTG to the T7 promoter present in the pET-28 a (+) vector. Sonication was performed to isolate the intracellular recombinant SP enzyme. The recombinant enzyme was cloned in such a way that it has both $\mathrm{N}$ and Cterminal His-tag. The recombinant enzyme with His-tag will bind to the Ni atom in the Ni-NTA column while the remaining intracellular enzymes are washed out from the column by $20 \mathrm{mM}$ wash buffer. The 
recombinant SP enzyme was eluted from the column by using the higher concentration imidazole i.e 300 $\mathrm{mM}$ elution buffers. From the SDS PAGE gel image the molecular weight of SP enzyme was found to $52 \mathrm{kDa}$ (Fig 4).

\section{Protease assay}

The sigma's non-specific protease assay was performed to find the activity of the purified protein. the protein content of the purified SP was determined by Bradford assay. The enzyme activity of the induced protein was found to be $50 \mathrm{U} / \mathrm{mL}$ and the protein concentration was about $1.1 \mathrm{mg} / \mathrm{mL}$. The enzyme activity of the purified was found to be $200 \mathrm{U} / \mathrm{mL}$ and the protein concentration was about $0.646 \mathrm{mg} / \mathrm{mL}$. the specific activity of the purified protein was found to be $309.59 \mathrm{U} / \mathrm{mg}$ (Table 3).

\section{In vitro cytotoxicity}

As per ISO 10993:5, the test sample Protein (Serrapeptase) showed Slight cytotoxic reactivity to PC-12 cells after $24 \mathrm{~h}$ contact. Control gave none cytotoxic reactivity as expected (Table 4).

\section{Insulin amyloid degradation}

The insulin amyloids were formed by incubating insulin solution at $65^{\circ} \mathrm{C}$ for 2 hours to $24 \mathrm{~h}$ and at each time interval; it was treated with SP and incubated at $37^{\circ} \mathrm{C}$ for $1 \mathrm{~h}$. The formation and degradation of insulin amyloids 14 were confirmed by turbidity assay.

For turbidity assay, $10 \mu \mathrm{l}$ of formed insulin amyloid at each time interval was added to $1 \mathrm{~mL}$ of PBS buffer and the $O D$ at $600 \mathrm{~nm}$ was measured. Insoluble protein aggregates can be detected at $600 \mathrm{~nm}$ and hence the presence of insulin amyloids and the reduction in the insulin amyloid due to SP treatment can be analysed using the OD values. From Fig $5 \mathbf{a}$, it is clear that SP treated samples have a lesser OD than the untreated ones indicating that SP has the potential to degrade insulin amyloids. Fig $\mathbf{5} \mathbf{b}$ shows the increase in the percentage of degradation of insulin amyloids at each time interval.

\section{Caseinolytic Assay}

The purified enzyme was loaded in wells of the casein agar plate and incubated at $28^{\circ} \mathrm{C}$ for overnight. The wild type enzyme was also loaded in the separate casein plate. IPTG induction with $16 \mathrm{~h}$ incubation period showed a zone of clearance. The zone of clearance was not observed in $4 \mathrm{~h}$ of induced and uninduced sonicated sample and whereas the purified supernatant of the induced and uninduced sample did not show any zone clearance this indicated that there is no leaky expression of the enzyme so we can confirm the expression was only inside the cell ( Fig 6). The wild type strain sample also showed a zone of clearance in the plate assay it was used as a positive control. This indicates that the enzyme is active and has the property of proteolytic activity.

\section{Discussion}


In this study, cloning of SP gene into pET28 was successfully done without the formation of any inclusion bodies and it was enzymatically active. The plasmid was transformed into E.coli BL21 as it is the best for protein expression studies and IPTG induction was found to be more prominent at $37^{\circ} \mathrm{C}$. Since SP was intracellular enzyme it was isolated by sonication process. Expression studies have also done in Pichia pastoris using yeast transfer vector and induced using methanol and found the induced proteins to be in the supernatant. Also, a band size of $52 \mathrm{kDa}$ as in our study was observed in SDS PAGE. A study shows that the SP gene cloned in PJET 1.2 with 487 amino acid [22]. But few studies revealed that the gene was cloned into PTSP26 vector and protein was not expressed in the culture medium but was detected inside the cells and the protein molecular weight was $50 \mathrm{kDa}$ which is determined by SDS PAGE[15]. In another case, the protein was expressed into the culture medium with 48 - $60 \mathrm{kDa}$ molecular weight[19] and when cloned into pET32a, there was the presence of inclusion bodies and it was[27]enzymatically inactive. Literature studies have shown that when SP was cloned into pET28b vector and performed IPTG induction at $37^{\circ} \mathrm{C}$ for 4 hours inducedSP was found in the supernatant. Also, there were no inclusion bodies formed and it was also enzymatically active[20]. A study shows that SP isolated from Serratia marcescens TS1 has a molecular weight of $56 \mathrm{kDa}$ and it has maximum caseinolytic activity at $40^{\circ} \mathrm{C}$ and $\mathrm{pH} 8.0[28]$. The serine protease gene cloned in pPIC9K/ pro from Chaetomium thermophilum and the molecular weight was found to be $44 \mathrm{kDa}$.

In this study, insulin was used as a model protein to study the amyloidogenic potential of SP. SP also showed the potential to degrade insulin amyloids formed in vitro. Turbidity assay indicates the reduction in insulin amyloids after treatment with SP. A maximum of $25 \%$ degradation of insulin amyloid was observed at $24 \mathrm{~h}$ time interval. Study on insulin amyloid degradation have been carried out using commercially available SP where they studied the formation and degradation using assays like ThT spectrofluorometer, FTIR, CD spectroscopy, DLS, turbidity assay, MTT assay in PC12 cell lines that are specific to study amyloids and in vivo zebrafish studies and confirmed that SP can degrade insulin amyloids. The degradation capacity of the commercially available SP used in the literature study is higher than the recombinant SP used in our study which maybe because of the better formulation of the commercial enzyme. The PC12 cell line shows that after treatment of SP enzyme the $99 \%$ cells are viable that SP not toxic to PC12 cell line [14]. A study on amyloid fibril inhibit by using surfactants $(1,2-$ dihexanoyl-sn-glycerol-3-phosphocholine (di-C7-PC) and 1,2- diheptanoyl-sn-glycerol-3-phosphocholine (di-C7-PC). Both the surfactants at $4 \mathrm{mM}$ concentration inhibited amyloid fibril and when they subjected to cytotoxicity study, either of the surfactants is cytotoxicity in both PC12 and SH-SY5Y cell lines [30].The degradation capacity indicates, SP can also degrade other amyloids like $\beta$-amyloids etc. that are the evident cause of many deadly disorders. Further studies are required to prove the amyloidogenic potential of SP.

\section{Conclusion}

The SP gene was successfully cloned and expressed in pET-28 a (+) vector. Since the purified enzyme has degraded $25 \%$ insulin amyloid in $24 \mathrm{~h}$, it can be used for further in vivo insulin amyloid degradation study. The recombinant enzyme shows the zone of clearance in casein agar plate for $16 \mathrm{~h}$ IPTG 
induction. SP showed slight cytotoxicity reactivity to PC-12 cells after $24 \mathrm{~h}$ contact. This study shows that cloning and the expression of SP will reduce the time and cost of production of SP from wild type strain which can be used for the treatment of amyloid-related diseases.

\section{Declarations}

Ethics approval and consent to participate

Not applicable

Consent for publication

Not applicable

Availability of data and material

Not applicable

Competing interests

The authors declare that they have no conflict of interest in the publication.

\section{Funding}

There was no funding available for this work

\section{Authors' contributions}

RV conceptualized and performed all the experiments. SG investigated and wrote the original manuscript. ES supervised and, administrated the whole project. All authors read and approved the final manuscript.

\section{Acknowledgments}

The authors are grateful to SRMIST, India for providing tremendous facilities and support to carry out the work.

\section{Abbreviations}

SP - Serrapeptase

IPTG- Isopropyl $\beta$ - d-1-thiogalactopyranoside

SDS-PAGE - Sodium Dodecyl Sulphate-PolyAcrylamide Gel Electrophoresis

PC12 - Pheochromocytoma Cells 
FTIR - Fourier-transform infrared spectroscopy

CD spectroscopy - Circular dichroism spectroscopy

DLS - Dynamic light scattering

MTT - 3-(4,5-Dimethylthiazol-2-yl)-2,5-Diphenyltetrazolium Bromide

LB broth - Luria-Bertani broth

NEB - New England Biolabs

\section{References}

1. Wechalekar, A.D., Schonland, S.O., Kastritis, E., Gillmore, J.D., Dimopoulos, M.A., Lane, T., Foli, A., Foard, D., Milani, P., Rannigan, L. and Hegenbart, U. A European collaborative study of treatment outcomes in 346 patients with cardiac stage III AL amyloidosis. Blood, 2013,121(17), 3420-3427. DOI:1182/blood-2012-12-473066.

2. Merlini, G., Seldin, D.C. and Gertz, M.A. Amyloidosis: pathogenesis and new therapeutic options. Journal of Clinical Oncology, 2011, 29(14),p.1924. DOI:1200/JC0.2010.32.2271.

3. Mangla, A., Kim, G.J., Agarwal, N., Khurana, S., Catchatourian, R. and Jiang, J.J. Localized insulin amyloidosis with use of concentrated insulin: a potential Diabetic Medicine, 2016, 33(12), pp.e32e35. DOI:10.1111/dme.13137.

4. Sipe, Jean D., Merrill D. Benson, Joel N. Buxbaum, Shu-ichi Ikeda, Giampaolo Merlini, Maria JM Saraiva, and Per Westermark. Nomenclature 2014: Amyloid fibril proteins and clinical classification of the amyloidosis. 2014: 221-224. DOI:3109/13506129.2014.964858.

5. Nilsson, M.R. Insulin amyloid at injection sites of patients with diabetes. Amyloid, 2016, 23(3), pp.139-147. DOI: 1080/13506129.2016.1179183

6. Datta, S., Rajnish, K.N., George Priya Doss, C., Melvin Samuel, S., Selvarajan, E. and Zayed, H., 2020. Enzyme therapy: a forerunner in catalyzing a healthy society?. Expert Opinion on Biological Therapy, 20(10), pp.1151-1174.DOI: 1146/annurev.bi.55.070186.003123

7. Singh, R., Kumar, M., Mittal, A. and Mehta, P.K. Microbial enzymes: industrial progress in $21 \mathrm{st}$ century. 3 Biotech, 2016, 6(2), p.174. DOI:1007/s13205-016-0485-8

8. Bach, E., Sant'Anna, V., Daroit, D.J., Corrêa, A.P.F., Segalin, J. and Brandelli, A. Production, one-step purification, and characterization of a keratinolytic protease from Serratia marcescens P3. Process biochemistry, 2012, 47(12), pp.2455-2462. DOI:1016/j.procbio.2012.10.007

9. Jickling, G.C., Zhan, X., Ander, B.P., Turner, R.J., Stamova, B., Xu, H., Tian, Y., Liu, D., Davis, R.R., Lapchak, P.A. and Sharp, F.R. Genome response to tissue plasminogen activator in experimental ischemic stroke. BMC genomics, 2010, 11(1), p.254. DOI: 1186/1471-2164-11-254 
10. Gopinath, S., Venkataprasad, R., Rajnish, K.N., Datta, S. and Selvarajan, E., 2020. Enhancement of Serrapeptase Hyper Producing Mutant by Combined Chemical and UV Mutagenesis and its Potential for Fibrinolytic Activity. J Pure Appl Microbiol, 14(2), pp.1295-

1303.https://doi.org/10.22207/JPAM.14.2.25

11. Sellman, S. Serrapeptase, An Amazing Gift from The Silk Worm. World rights reserved. 2003

12. Ethiraj, S. and Gopinath, S., 2017. Production, purification, characterization, immobilization, and application of Serrapeptase: a review. Frontiers in biology, 12(5), pp.333-348.

https://doi.org/10.1007/s11515-017-1461-3

13. Klein, G. and Kullich, W. Short-term treatment of painful osteoarthritis of the knee with oral enzymes. Clinical Drug Investigation, 19(1), 2000, 15-23. DOI: 10.2165/00044011-200019010-00003

14. Metkar, S.K., Girigoswami, A., Murugesan, R. and Girigoswami, K. In vitro and in vivo insulin amyloid degradation mediated by Serratiopeptidase. Materials Science and Engineering: C, 70, 2017, pp.728735. DOI: 1016/j.msec.2016.09.049

15. Nakahama K, Yoshimura K, Marumoto R, Kikuchi M, Lee I S, Hase T, Matsubara H. Cloning and sequencing of Serratia protease gene. Nucleic Acids Res,1986, 14(14): 5843-5855.

Doi: 1093/nar/14.14.5843

16. Hege, T. and Baumann, $U$. The conserved methionine residue of the metzincins: a site-directed mutagenesis study. Journal of molecular biology, 314(2),2001, pp.181-186.

DOI: 1006/jmbi.2001.5125

17. Matsumoto, K., Maeda, H., Takata, K., Kamata, R. and Okamura, R. Purification and characterization of four proteases from a clinical isolate of Serratia marcescenskums 3958. Journal of bacteriology, 157(1),1984, pp.225-232. PMID: 6418718

18. Tao, J.L., Wang, X.D., Shen, Y.L. and Wei, D.ZStrategy for the improvement of prodigiosin production by a Serratia marcescens mutant through fed-batch fermentation. World Journal of Microbiology and Biotechnology, 21(6-7), 2005, pp.969-972.

19. Braunagel, S.C. and Benedik, M.J. The metalloprotease gene of Serratia marcescens strain SM6. Molecular and General Genetics MGG, 222(2-3),1990, pp.446-451. DOI: 1007/bf00633854

20. Selan, L., Papa, R., Tilotta, M., Vrenna, G., Carpentieri, A., Amoresano, A., Pucci, P. and Artini, M. Serratiopeptidase: a well-known metalloprotease with a new non-proteolytic activity against aureus biofilm. BMC microbiology, 15(1),2015, p.207. DOI: 10.1186/s12866-015-0548-8

21. Kaviyarasi, N.S., Sarkar, S. and Suryanarayana, V.V.S. Characterization of a Gene Encoding Serrapeptidase from Serratia Marcescens Strain (SRM) MTCC 8708, a Plant Isolate. International Journal of Current Microbiology and Applied Sciences; 2(8), 2015, pp.206-214.

22. Kaviyarasi, N.S., Prashatha, C.N. and Suryanarayana, V.V.S. In silico analysis of inhibitor and substrate binding site of serrapeptidase from Serratia marcescens MTCC 8708 . International Journal of Pharmacy and Pharmaceutical Sciences, 8(4), 2016, pp.123-128. 
23. Pakhale, S.V. and Bhagwat, S.S. Purification of serratiopeptidase from Serratia marcescens NRRL B 23112 using ultrasound assisted three phase partitioning. Ultrasonics sonochemistry, 31,2016, pp.532-538.DOI: 1016/j.ultsonch.2016.01.037

24. Gupte, V. and Luthra, U.Analytical techniques for serratiopeptidase: A review. Journal of pharmaceutical analysis, 7(4), 2017, pp.203-207. Doi:1016/j.jpha.2017.03.005

25. Cupp-enyard, C. Sigma's Non-specific Protease Activiy Assay - Caesin as a Asubstrate. Journal of visualized experiments19, 899, 2008. DOI: 3791/89269

26. He, Fanglian. "Plasmid DNA extraction from coli using alkaline lysis method." Biology Protocol30 2011, 1-3. DOI: $10.21769 /$ BioProtoc.30

27. UmaMaheswari, T., Hemalatha, T., Sankaranarayanan, P. and Puvanakrishnan, R., 2016. Enzyme therapy: current perspectives. PMID: 26891548

28. Tariq, A.L., Reyaz, A.L. and Prabakaran, J.J. Purification and characterization of $56 \mathrm{KDa}$ cold active protease from Serratia marcescens. African Journal of Microbiology Research, 5(32), 2011, pp.58415847.DOI: 5897/AJMR11.351

29. Li, A.N. and Li, D.C. Cloning, expression and characterization of the serine protease gene from Chaetomium thermophilum. Journal of applied microbiology, 106(2),2009, pp.369380.DOI: 1111/j.1365-2672.2008.04042.x

30. Wang, S.S.S., Liu, K.N. and Han, T.C. Amyloid fibrillation and cytotoxicity of insulin are inhibited by the amphiphilic surfactants. Biochimica et Biophysica Acta (BBA)-Molecular Basis of Disease, 1802(6),2010, pp.519-530.DOI: 1016/j.bbadis.2010.02.008

\section{Tables}

\begin{tabular}{|l|l|}
\hline Name of the Primer & Primer sequence \\
\hline Forwad primer (Ndel) & 5'GCGCATATGCAATCTACTAAAAAGGC3' \\
\hline Reverse primer (HindIII) & 5'GCGAAGCTTACACGATAAAGTCAGTGGC3' \\
\hline
\end{tabular}

Table 1. Primer sequence 


\begin{tabular}{|l|l|l|}
\hline S.No & Grade (\%) & Reactivity \\
\hline 1 & 0 & None \\
\hline 2 & $1-20$ & Slight \\
\hline 3 & $21-50$ & Mild \\
\hline 4 & $51-70$ & Moderate \\
\hline 5 & $>71$ & Severe \\
\hline
\end{tabular}

Table 2

\begin{tabular}{|l|l|l|l|l|}
\hline Protein fraction & $\begin{array}{l}\text { Protein content } \\
(\mathrm{mg} / \mathrm{ml})\end{array}$ & $\begin{array}{l}\text { Activity } \\
\text { (units/ml) }\end{array}$ & $\begin{array}{l}\text { Specific activity } \\
\text { (units/mg) }\end{array}$ & $\begin{array}{l}\text { Purification } \\
\text { fold }\end{array}$ \\
\hline Crude & 1.1 & 50 & 45.45 & 1.0 \\
\hline $\begin{array}{l}\text { Nickel affinity } \\
\text { chromatography }\end{array}$ & 0.646 & 200 & 309.59 & 6.8 \\
\hline
\end{tabular}

Table 3 . Purification fold of serrapeptase 


\begin{tabular}{|c|c|c|c|c|c|}
\hline \multirow[t]{2}{*}{$\begin{array}{l}\text { Sample } \\
\text { code }\end{array}$} & \multicolumn{2}{|c|}{ Sample Particulars } & \multirow[t]{2}{*}{$\begin{array}{l}\text { Cytotoxicity } \\
\text { (\%) }\end{array}$} & \multirow[t]{2}{*}{ Cell viability (\%) } & \multirow[t]{2}{*}{$\begin{array}{l}\text { Cytotoxic } \\
\text { Reactivity }\end{array}$} \\
\hline & Description & $\begin{array}{l}\text { Conc } \\
(\mu \mathrm{g})\end{array}$ & & & \\
\hline \multirow[t]{5}{*}{ BT 8} & \multirow[t]{5}{*}{$\begin{array}{l}\text { Protein } \\
\text { (Serrapeptase) }\end{array}$} & 5 & 0 & $>99$ & None \\
\hline & & 25 & 0 & $>99$ & None \\
\hline & & 50 & 0 & $>99$ & None \\
\hline & & 75 & 0 & $>99$ & None \\
\hline & & 100 & 5.1 & $>99$ & Slight \\
\hline
\end{tabular}

Table 4 . In vitro cytotoxicity

Figures 
$1 \mathrm{~kb}$ Ladder

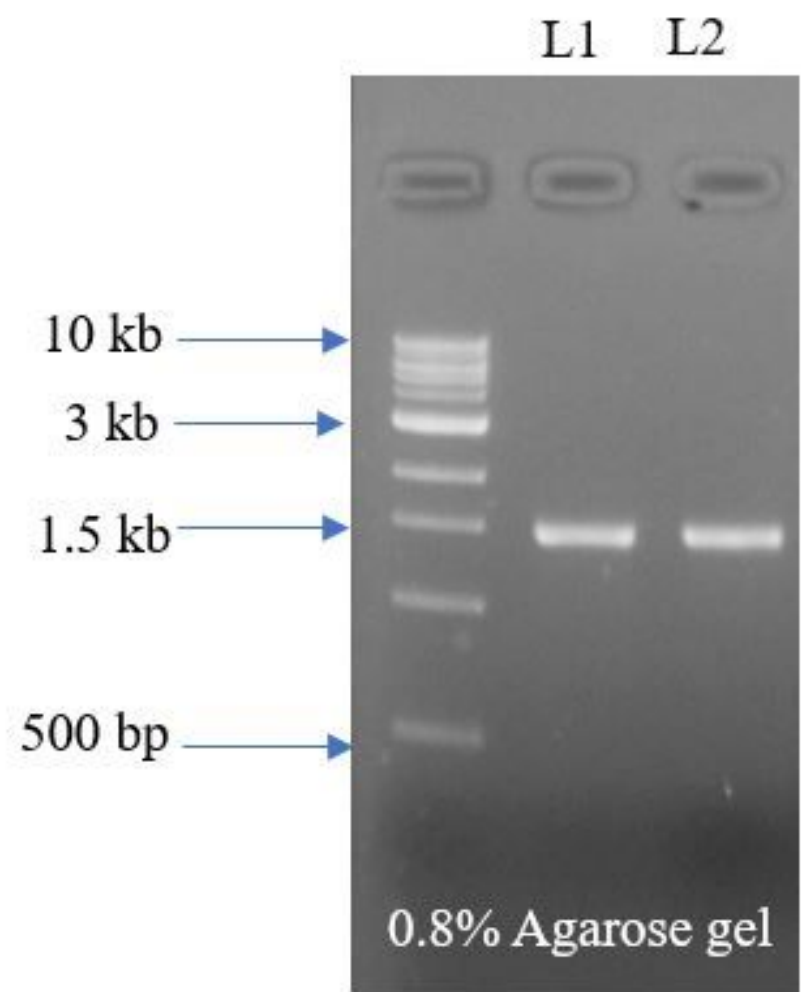

Fig 1. PCR amplification of SP gene

L1 - L2Serrapeptase gene amplified by Phusion DNA poly

Figure 1

PCR amplification of SP gene 


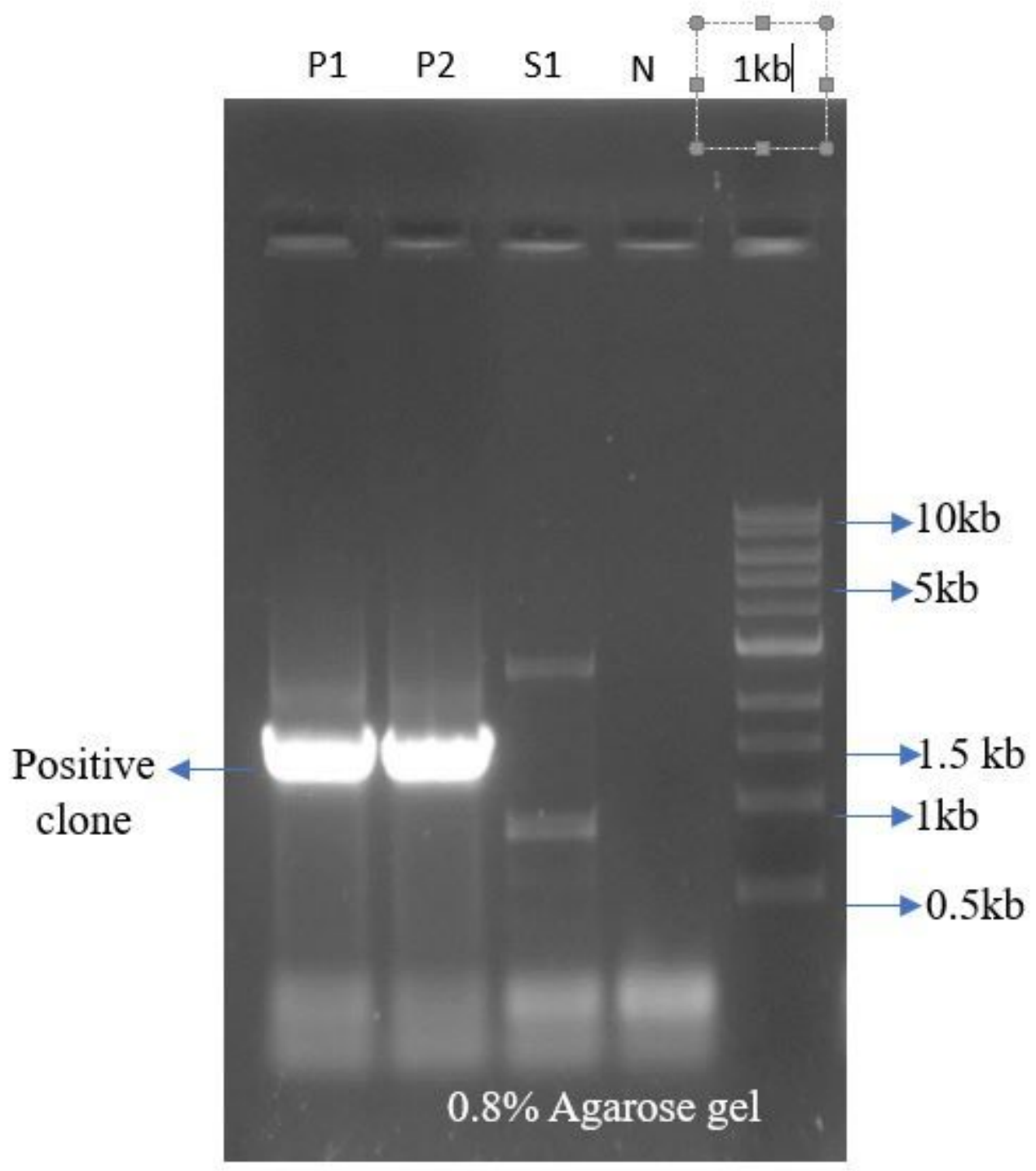

Fig 2. Colony PCR

P1-P2 : Positive Colony, S1: Negative colony, N : Negative Control

Figure 2

Colony PCR 


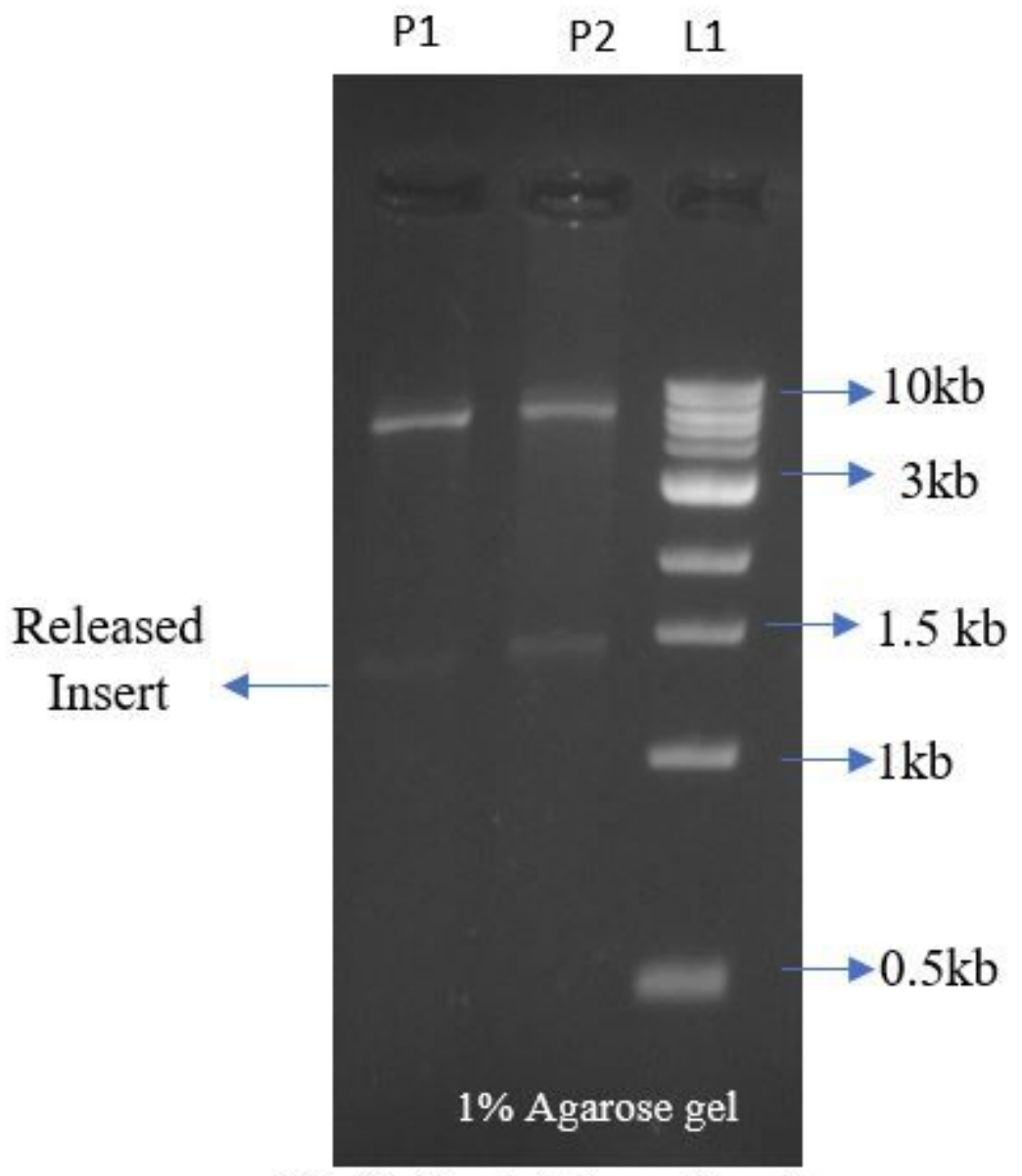

Fig 3. Restriction digestion

P1-P2 : Positive Colony, Ll: $1 \mathrm{~Kb}$ ladder

Figure 3

Restriction digestion 


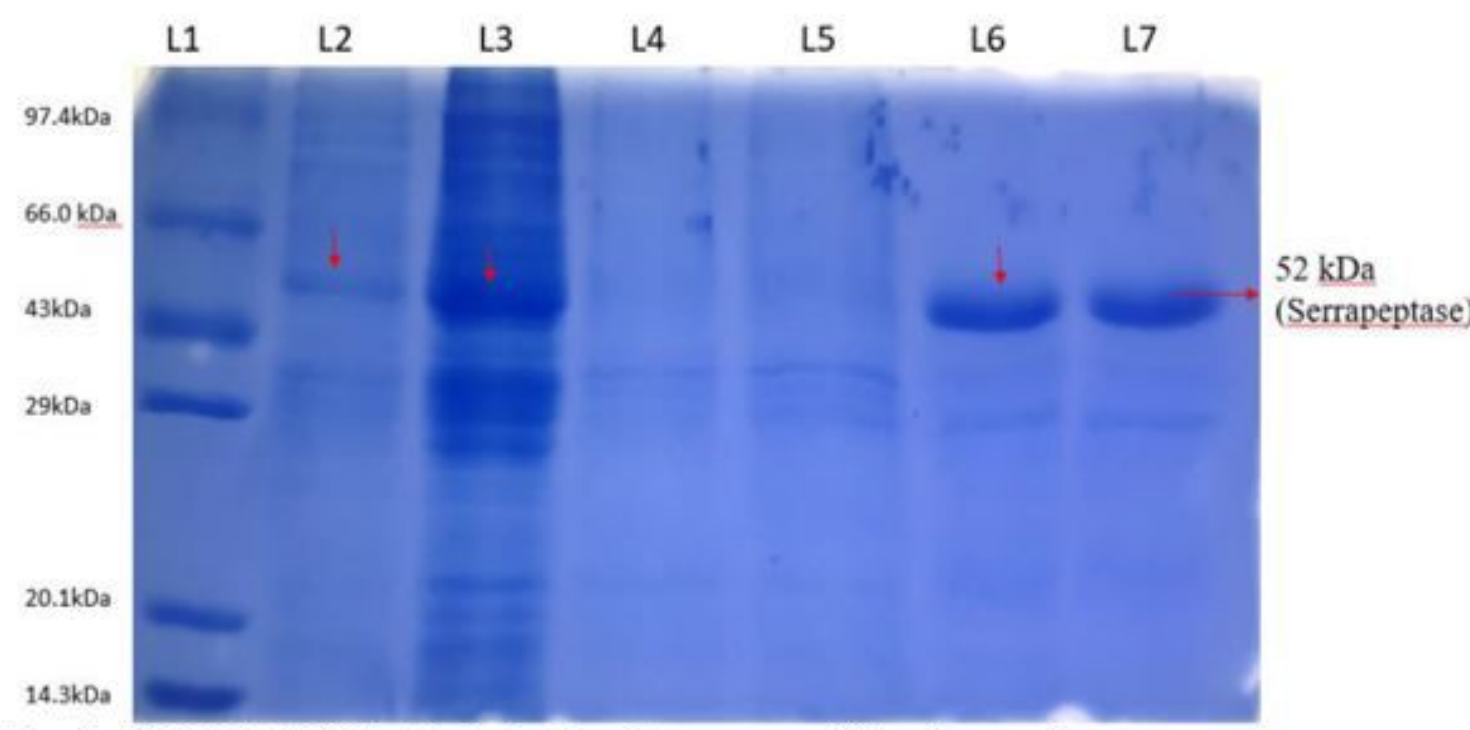

Fig 4. SDS PAGE of nickel column purification of serrapeptase

L1: Protein Marker, L2: uninduced protein, L3: induced protein, L4: flow through,L5: Wash, L6: Elution 1, L7: Elution 2

Figure 4

SDS PAGE of nickel column purification of serrapeptase

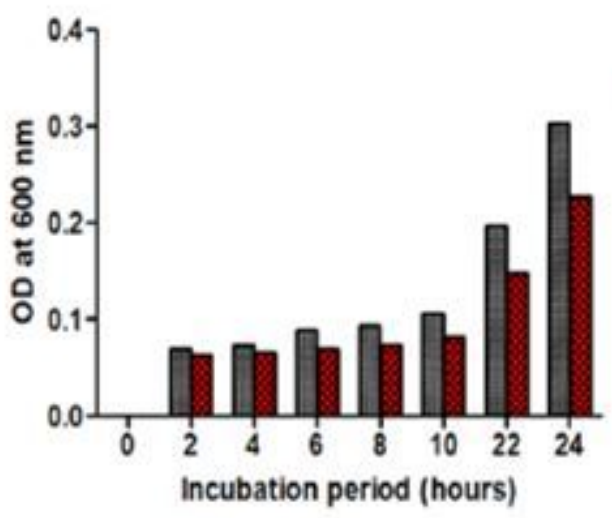

a.OD at $600 \mathrm{~nm}$ vs incubation period

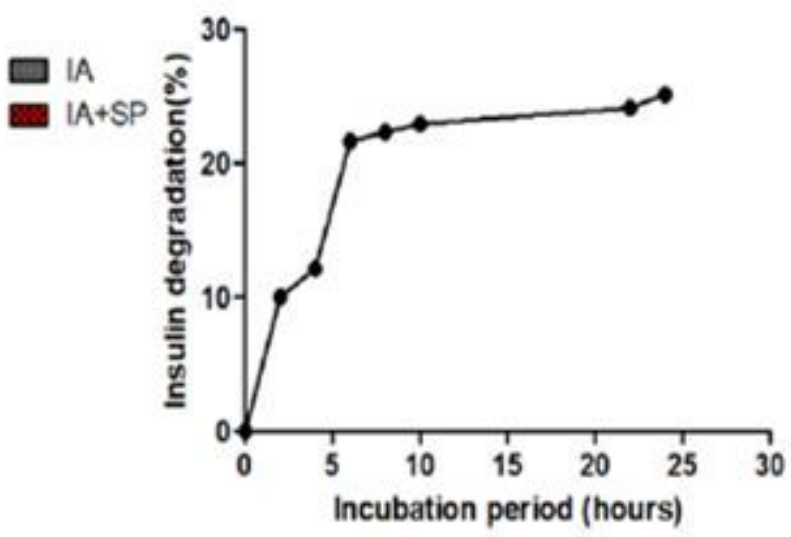

b. $\%$ insulin degradation vs incubation period.

Fig 5 . Turbidity assay. Effect of Serrapeptase against insulin amyloid degradation.

\section{Figure 5}

Turbidity assay. Effect of Serrapeptase against insulin amyloid degradation. 

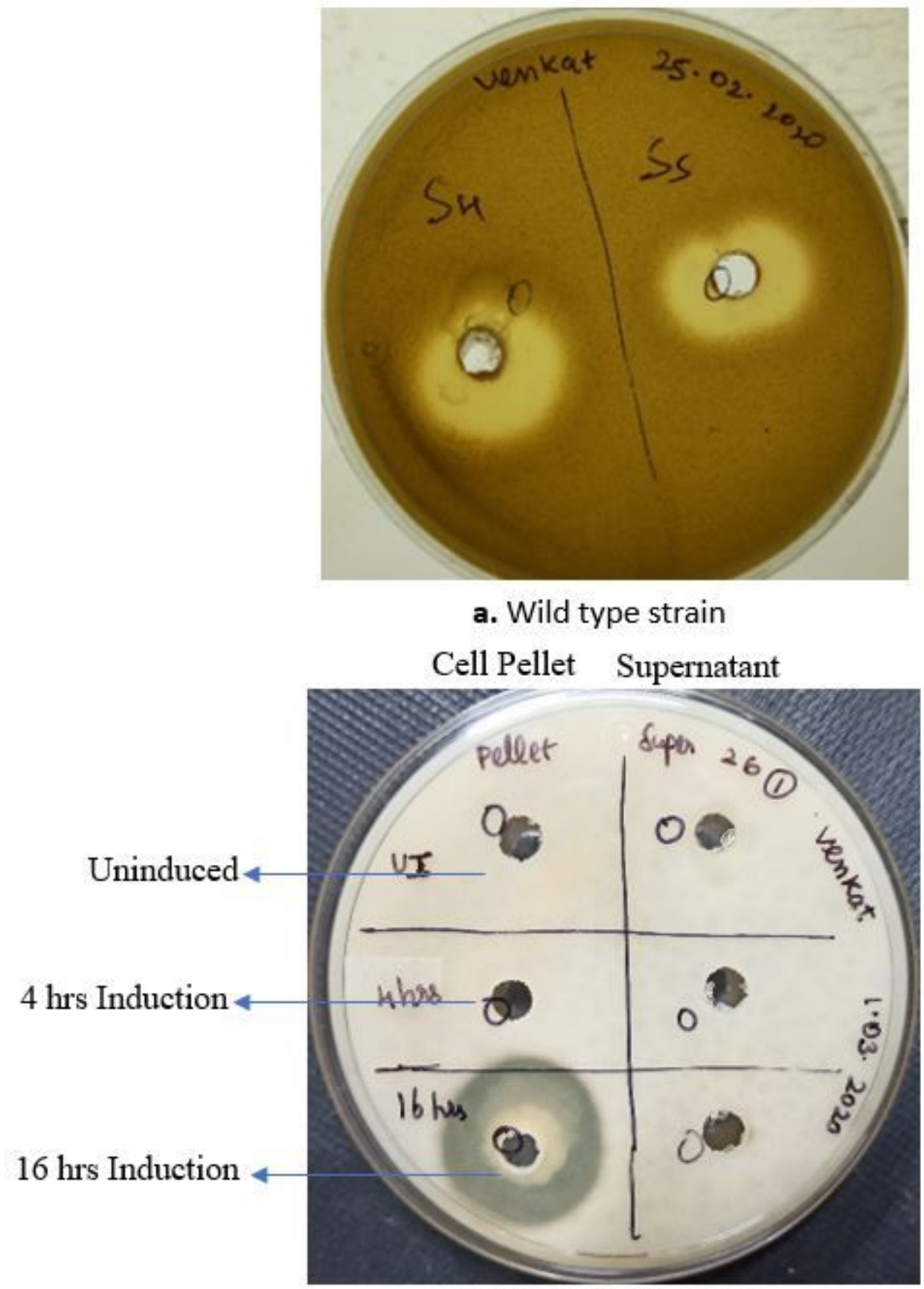

b. Recombinant strain

Fig 6. Caseinolytic assay

Figure 6

Caseinolytic assay 